\title{
唯識学派における仏の大悲について
}

\section{Paul Hoornaert}

大悲という仏徳は一切有情を集諦と苦諦から出離させんとする意志 (āśaya) で ある1)。『成唯識論』飞依れば大悲は仏の無漏善心所としての不害である2)。有為 法であるから一切有為法の寂滅としての滅諦に属さない。そして無漏であるから 集諦と苦諦にも属さない。苦集諦としての生死にも属さず，二乗の無余依涅槃に も属さない大悲は無住処涅槃に住する仏の功徳であって, 出世間道諦にのみ属し ている3)。護法の仏身論によっていえば，大悲は大菩提等のその他の有為仏法と 共に自受用身に属している。

大悲は救済への意志にとどまらず，行動（pratipatti）に向う意志である4)。生 死を出離した仏は有漏法の姿を取る化身となって常に生死に出生し，有情を解脱 へ導く。しかし，化身は有漏法に似た身であっても，自受用身に於ける大悲の所 産として自受用身と同様，無漏道諦にのみ属している5)。仏は常に生死飞住して いても，生死に熬縛される存在では決してない。

以下，主に護法の仏陀観に依りつつ大悲の解明のために次の二点を考察した。 (1)大悲と大菩提は不可分の関係にある。(2)大悲大菩提等の有為仏徳は無始 (anādikālika) の現行法である。

（1）大悲は盲目的な意志と行動ではなく，常に大菩提と隋行している。大悲 と同様に自受用身に属する大菩提は完全な無分別智と完全な後得智である。この 両智を離れては大悲は成り立ちえない。

（a）無分別智は法の空性（円成実性）を知る。この智は法が遍計所執性に於 て不生不滅本来俶静本来涅槃であるてとを知る。煩悩と業は遍計された法として 存在しない，即ち生じはしない，即ち苦を生じえない，即ち本来寂静であるから 道によって断ぜられるべき法ではない。そして苦諦に属する法は遍計所執性に於 て本来的に消滅しているから，それらの消滅 (nirodha) もまた不要である。換言 すれば，生死は遍計所執性の空に於て本来涅槃である6)。それ故に異生のように 遍計された生死に執著する根拠も存在しなければ，二乗のように遍計された生死 を恐れ，自分だけの解脱を目指して無余依涅槃へ逃走する根拠も存在しない。無 分別智は上述の真理を知ることは知るが，無著がいうょうに盲のようにその真理 
を閉じた目でみる。無分別智は真実を見，しかもそれを分別できない愚か者のよ うであり，或はそれを言葉に表わしえないおしのようでもある7)。

（b） 無分別智が見る真理を分別して理解できる智慧は無分別智と随行する有 分別の後得智である。有分別といっても, 後得智は無分別智を相伴っている限り, 無倒かつ無漏の分別である。仏は完全な無分別智に到達したからこそ，完全な有 分別智をも得た。上述の真理を完全に理解する知慧は仏の後得智である。とのよ らな知慧を有する仏は遍計された生死に執著もせず，それを恐れて二乗の無余依 涅槃へ逃亡することもない。

しかし，後得智が遍計された生死の無だけを知る智慧にすぎないならば，積極 的に生死に住し有情の苦を無くそうといら大悲に十分な基盤はない。生死が依他 起法として存在するからてそ大悲に有効な領域が存する。そして後得智が依他起 法としての生死をあるがままに知るからてそ，生死を捨てない大悲が成立する。 依他起法としての生死が刹那滅にして遍計所執性について空であるてとを知る後 得智に基づく大悲は執著するてとも恐怖するてともなく生死に住する。更に，後 得智に基づかないならば，大悲は有情の救済に対しては有効ではありえない。仏 は，他心知，神通，四無礙解等を含む後得智によって夫夫の有情に適った化身を 装い，適切な説教を行ら善巧方便を用いて一切有情を解脱へ導く。つまり，後得 智がなければ，大悲は成立しえない。しかし，無分別智なしには後得智も存在し えない。大悲は完全な無分別と分別の両智と不可分である。大菩提のない心には 大悲もない。大悲のない心は大菩提のない心である。

（2）完全な無漏有為法としての大菩提大悲等は究竟転依の瞬間に於て初めて 生起する。『成唯識論』は転依を二の意味に解釈する：（a）無為なる真如の転 換，(b) 有為なる識の転換。真如の転換は有垢位から無垢位への転換である。 無為は不変異であるから, 真如の転換とは真如が変異して初めて清浄なるものと して生起するてとではない。真如の転換は, 煩悩所知障の外来垢が滅するてとに よって真如の本来清浄が顕現するてとである。しかし, 二障が滅するとは, 有漏 識が完全な無漏識へ転換するととである。従って, 完全な無漏有為が生起するて とによって真如は完全に顕現する。無為の転依は有為の転依によっており，それ と同時に起こる。仏身論によっていえば，完全な無漏有為である自受用身が生起 するととによって, 真如の完全な顕現である自性身が得られ, 自受用身に属する 大悲の所産である他受用身と化身も生起する。有為の識の転換が護法の転依説の 中心であるから，彼の仏身論の中心課題は自受用身にある。そしてそれに一致し 


\section{唯識学派における仏の大悲について (P. Hoornaert)}

て，彼の種姓論は自受用身，即ち大菩提大悲等の生起に対する種姓が具わってい るかいないかに視点している。

さて，自受用身の生起の因縁であるが，有漏法は無漏法の因緣であり尜ない99。 そして無為法が因縁でありえないから，無漏有為法は必ず無漏有為法から生ずる。 しかしその場合，無漏有為法の因縁は無始であるといわざるを得ない。大菩提等 の生起は大菩提等の無始の本有種子に依っている。因縁としての仏性は無始の有 為法でなければならない。そのととは解脱の可能性の面からも要請される。とい うのは，生死が無始であれば，解脱の種子も無始でなければならない。我執と法 執の俱生種子の対治策としては大菩提大悲等の無始の種子が要請される。

次に，大菩提大悲等の種子が成長しなければ，即ち重習されなければ，それら は現行の大菩提大悲等を生じえない10)。乙の成長は大乗法を聞き，それに対する 信解等から始まる。しかし，大乗法を聞くことは化身による大乗法の説法を前提 としている。そして次第の如く化身は大悲を，大悲は後得智を，後得智は無分別 智を前提としている11)。要するに，大菩提等の種子から初めて現行の大菩提等が 生起することは既に現行の大菩提，現行の大悲，現行の自受用身を前提としてい る。仏となるととは常に既に他の仏が現存するてとを前提としている。それぞれ の仏の自受用身，大菩提大悲等に始まりがあるが，自受用身，大菩提大悲等その ものには始まりはない。それぞれの相続における真如と識の転依に始まりがある が，転依そのものは無始である。無始の生死に対しては無始以来生死を出離した 仏の間断のない自受用身，そして無始以来生死に出生する化身が現行法として存 在しなければならない。『大乗荘厳経論』は最初の仏（ādibuddha）が存在しない と言明する12)。乙れは現行法としての自受用身，大菩提，大悲，化身，大乗法等 が無始であることを意味している。

1) Mahāyānasūtrālamikāra (S. Lévi ed., 以下 MSA) XX-XXI. 43。

2) T. 1585, vol. $31,13 \mathrm{c} 28 \mathrm{ff} . ; 30 \mathrm{~b} 28 \mathrm{ff} . \circ$

3） T. 1585, 57a 17-22; 『仏地経論』T. 1530, vol. 26, 304b 10-13。

4) MSA XVII. $35 \circ$ 5) T. $1585,57 \mathrm{a} 20-22 ; 58 \mathrm{c}$ 27-29。

6) Derge, Sems-tsam Tsi 211b 1-213a4（安慧橎 ad MSA XIX. 52）; 『捸大乗論』T. 1594, vol. $31,149 \mathrm{a} 13-16$ 。

7) T. 1594, 148a 5-16。
8) T. $1585,51 \mathrm{a} 3-16$ 。
9) id., $8 \mathrm{c} 16$ 。
10) id., 9a 7-10。

11）『成唯識論述記』T. 1830 , vol. 43, 556a 16-17；597b 27-c1。 12） MSA IX 77。 註：拙稿「安慧の識論について」(『印仏研』vol. 31，2） p. 152，上段 2 行目の「依止」 を「似て」に訂正する。 (東北大学大学院) 